\begin{tabular}{c} 
Volume and Issues Obtainable at Center for Sustainability Research and Consultancy \\
Journal of Business and Social Review in Emerging Economies \\
ISSN: 2519-089X (E): 2519-0326 \\
Volume 3: Issue 2December 2017 \\
CSRᄃ \\
Journal homepage: $\underline{\text { www.publishing.globalcsrc.org/jbsee }}$ \\
\hline
\end{tabular}

\title{
A Validity Study of Malay-translated Version of the Modified Caregivers Strain Index Questionnaire (M-CSI-M)
}

\author{
${ }^{1}$ Mohan S.Ramasamy, ${ }^{2}$ Rahimah Ibrahim, ${ }^{3}$ Zainal Madon, ${ }^{4}$ Zarinah Arshat \\ ${ }^{1}$ Institute Of Gerontology, Universiti Putra Malaysia. rmohan04@gmail.com \\ ${ }^{2}$ Associate Prof., Institute Of Gerontology, Universiti Putra Malaysia \\ ${ }^{3}$ Department of Human Development and Family, Faculty of Human Ecology, Universiti Putra Malaysia \\ ${ }^{4}$ Department of Human Development and Family, Faculty of Human Ecology, Universiti Putra Malaysia
}

\begin{tabular}{l}
\hline ARTICLEDETAILS \\
\hline History \\
Revised format: Nov 2017 \\
AvailableOnline: Dec 2017 \\
Keywords \\
Informal care providers, \\
caregiving strain, \\
validation, \\
modified caregiver strain \\
index (m-csi), \\
National language of \\
Malaysia(Bahasa Melayu) \\
\end{tabular}

JEL Classification:

H4O, $H 49$

\section{ABSTRACT}

Purpose:The population all around the world varies in accordance with the cross cultural survey instruments or scales. Doctors and nurses and other health practitioners need unlimited access to the basic working concepts in order to provide consistent and good health care to the patients in their various regions. The basic aim of the survey is to explain the Modified Caregiver Strain Index, (M-CSI) in the Malaysian language. Another aim of this survey is to analyze the impact of the Malay translated version of the Modified Caregiver Strain Index, (M-CSI-M)

Methods: The instrument was translated ahead first and then rebranded by a panel in line with the translation strategy. This was then reconciled and the authenticity was checked by the Malaysian Institute of translation and Books as experts literature and content. After methodological approaches for the translation, adaptation and transcultural validation of Modified Caregiver Strain Index (M-CSI) the recently updated version of Malaysia was sent to 50 care givers who were not in the formal sector. These caregivers took care of the elderly folk who were suffering from Parkinson's disease. These were got from the Parkinson Malaysia (MPDA) and the University Kebangsaan Malaysia (UKM) Medical Centre in May 2017

Results: The Malaysian Modified Caregiver Strain Index (M-CSI-M) has sound validity, that is depicted by the inner consistency of the Cronbach alpha of 0.75.the index is also highly looked upon and thus a valuable opinion and point of reference.in summary it is an essential tool that is used to determine the stress levels of various caregivers that operate outside the formal sector in the quest to take care of Parkinson's disease patients in Malaysia. This index is of high value that even the doctors and social workers as well as psychologists employ the use of it to help locate the exact point of stresses affecting the caregivers for the elderly with Parkinson's diseases in Malaysia

(C) 2017 The authors, under a Creative Commons AttributionNonCommercial 4.0

Corresponding author's email address: rmohan04@gmail.com

Recommended citation:Ramasamy M.S, Ibrahim.R ,Madon.Z, Arshat.Z. (2017). A Validity Study of Malaytranslated Version of the Modified Caregivers Strain Index Questionnaire (M-CSI-M).Journal of Business and Social Review in Emerging Economies, 3(2) 217-226.DOI:https://doi.org/10.26710/jbsee.v3i2.47 


\section{Introduction}

Malaysia is located in the southern region of Asia and it has a population of 31.7 million citizensfrom different ethnic groups, cultures and religions. Malaysia comprises three major ethnic groups: the original Malaysians (68.6\%), the Chinese population (23.4\%), the country also has an Indian population of about (7.0\%) and the rest of the people comprising of foreign nationals and all $(1.0 \%)$ this is in sync with the Malaysian statisticsdepartment (2016).

Today we are confronting a growing aging population worldwide. For 2030 it is expected that the number of adults over 65 years will represent $20 \%$ of the population (Wan, et al., (2005). The investigations carried out during the last 20 years shows that people are living longer and with fewer disabilities compared with the previous generation (Freedman et al., Martin, and Schoeni, (2002), Journal on reorganization for an aging of America (2008). According to the Department of Statistics Malaysia (2014), $70 \%$ of the entire population of Malaysia is coming from the age group between 15 and 64 years of age. The pattern of this pointer is in accordance with the move of age structure towards aging population of Malaysia.

In the country, since the government administered and reverted terminal mental health services back to the society, informal care providers have had the sole mandate of taking care of their elderly relatives at their own homes. As per culture, Malaysian families make unanimous decisions to take care of the sick member of the family in the house and see the hospital service as their last option (Deva, P.M, 2004). However, at a given stage, being an informal care provider and at the same time to manage their own lives and attention to the family is difficult and demanding (Hansen, Archbold, \& Stewart, 2004; Sherwood, Given, Doorenbos, Given. (2004),Teschendorf et al., 2007). In the present years, the number of informal care providers of dependent elderly in family has increased and continues to increase due to the aging of the Malaysian population (Department of Statistics 2014). This demanding situation in Malaysia today, more informal care providers are expected to put his career and financial matters pending, as they juggle with part-time caregiving and full-time job requirements.

The informal care providers of dependent elderly can experience often caregiving pressure. For the reason of analyzing diligently this question, health professionals, counselors, psychologists and care giversperhaps require to put into usean easily managed measuring tools in their practices. In the context of Malaysia, an extra setback is to analyze if these measuring tools conceivedfrom the Western culture are authentic and reliable to evaluate the caregiving strain of the informal care providers.

There is a good number of self-evaluation tools have been developed to assess caregiving burden or stress level of informal care providers (Deekenjf et.al. (2003). These include Zarit Burden Interview, Caregiver Strain Index (CSI), Modified Caregiver Strain Index (M-CSI), Caregiver Burden Scale and Caregiver Reactions Assessment. The CSI is a short, simple and easily self-administered measurement scale (Robinson, B. C. (1983). The internal consistency, reliability is high with the Alpha Cronbach of 0.86, has a good construct validity correlated with the physical and emotional health of the care provider and with subjective opinions of the care giving parameter. It has been tried on care providers of cancer (OzlemUgur, CicekFadiloglu (2010) and in patients with incident cerebrovascular (Van ExelJ,et. al., 2004), and Post M, (2007). In Malaysia the Malaysian version of CSI has been validated (Othman Z, Wong ST. (2014), and was administered to 50 care providers of patients with cerebrovascular attended the clinic of hospital Umum Sarawak in December 2011. The Malaysian Caregiver Strain Index (CSI-M) has a good face validity and content, as well as inner consistency (Alpha Cronbach of 0.79) as indicated by Zahiruddin Othman and Wong Siong Teck (2014). The Malaysia Caregiver Strain Index (CSI-M), has been translated and validated based on the original Caregiver Strain Index (CSI), which has been validated in 1983 by Betsy C. Robinson.

As CSI has been developed on the basis of the community of English speakers, a process of cultural adaptation and the assessment of the validity of the new version are vital before the tool can be 
recommended for their use in the different cultures of the original. Currently it has been translated and validated for the Turks (OzlemUgur, FadilogluCicek, (2010), and the Chinese version for the Hong Kong Chinese (Chen ML, Hu LC., (2002).

The adjustments in the set-up of families are currently and in the foreseeable future will proceedwith having a consistent impact on the care giving answers required throughout the growing aging of the world population.Thus, a reliable, parsimonious, and convenient multi-cultural and multi-language measure of family care provider strain is likely to be a useful instrument for care provider research and practice in the foreseeable future. Care providers of older dependent people may often experience caregiving stress and burden. In order to assess systematically the issue related, health care professionals, counselors, psychologists and social workers in Malaysia may need to use the latest version of short and valid measures in their practice. In the context of Malaysia, one additional challenge is to examine whether a measurement developed in the Western culture is valid for Malaysian care providers of dependent elderly with Parkinson's disease. The caregivers have been noticed to be doing a jobencompassing the levying of advantages and disadvantages. Care providers can also get exposed to depression-related illnesses, grieving, tiredness, economic difficulties, as well as adjustments in the relationships on a social aspect.That can possibly culminate in problems of physical health (Thornton \& Travis, 2003). According to Megan Thornton and Shirley S. Travis Modified Caregiver Strain Index (MCSI) was adapted and validated as one of the latest version of screening instrument useful to identify any individual care provider and their care giving experiences.

In this study, the latest version of the Modified Caregiver Strain Index (MCSI) questionnaire was translated into the official language of Malaysia and its psychometric properties also will be assessed.

\section{Method (Participants and Instruments)}

\subsection{Construction of Malay version of Modified Caregivers Strain Index (MCSI-M)}

The exchange of the Modified Caregiver Strain Index (MCSI) a extra cutting-edge version of the Caregiver Strain Index (CSI) invented round the 12 months 1983. This index had been amended and developed in 2003 with the aid of sampling one hundred fifty units of family care companies supplying care for the aged dwelling in the society. The rating has been put at 2 marks in each 'yes' response and a single mark in every reply containing "sometimes". A greater whole mark consequently interprets to a higher stage of care giving stress or alternatively pressure (Travis et al., 2003; Thornton \&amp; Travis, 2003). In the Modified Caregiver Strain Index there is a better match giving us a simpler calculation. Even though the proof of the unique version of the CSI find the index is a dependable measurement, the modified version appears to be a better instrument to measure the strain between long-term care providers. Megan Thornton, Shirley S. Travis (2003), has additionally stated that the Modified Caregiver Strain Index has barely better interior reliability (alpha =.90) than the unique Index, as were knowledgeable in 1983 (alpha =.86). The two-week reliability test-retest used to be .88. It is a short, easily-to-manage, easily scored self-assessment instrument, and is correlated properly with variables regularly related with stress of caregiving and enduring pressure (Thornton, M., \&amp; Travis, S.S. (2003). According to Betsy C. Robinson and Megan Thornton and Shirley S. Travis the Modified Caregiver Strain Index may also be administered to individuals in the household looking after the elderly people with disabilities. The index evaluates thirteen dimensions including physique, financial tasks of the family, interactions with the community, required time, as nicely as work. By picking out the origins of the tension and quantifying the magnitude of the injury done, the index may additionally lead the choosing out of interventions which would be employed to beautify or rather enhance the anxiety amongst care givers and ofcourse alleviate the two dwelling prerequisites amongst care givers as properly as those who are being taken care of (Thornton, M., \&amp; Travis, S.S. (2003) and Robinson, B.C. (1983).

Although the process of translation, adaptation and validation of the various measures of scale for transcultural research are quite laborious and need sound planning as well as the use of advanced 
methodological processes rigorous such that reliable measurements are obtained and valid concept of interest in the target population (Sousa, V. D. And Rojjanasrirat, W. (2011). Strongly recommended methodological approaches for the forward-backward translation and amended Modified CSI for thee care givers who cannot speak English, much remains to be done to intercultural health research (Thornton, M., \& Travis, S. (2003). Between the two major categories of translation (symmetric as well as asymmetric), symmetric aspects are those approaches that are highly looked upon since they affect the fidelity in what is meant as well ascolloquialness either the dialect of origin (SL; the instrument's native dialect) and the dialect that is targeted (TL; the dialect) which is not a direct interpretation (Jones, E. G. and Kay, M. (1992). The whole point of the translation is to obtain a balance between the SL instrument as well as the TL instrument (Sperber, A. D. (2004). The symmetrical interpretation is the fundamental aspect that opens up the comparing of various responses of people of a particular culture to those of another (Sousa, V. D., Zauszniewski, J. A. Mendes, I. A. C. \& Zanetti, M. L., Jones (2005), E. G. and Kay, M. (1992) Jones, P. S. Lee, J. W., Phillips, L. R., Zhang, X. E. \&Jaceldo, K. B. (2001) and the determination of the rates the most significant aspects of cross-cultural: equivalence semantics, conceptual, content, criterion and technique (Hilton, A. \&Skrutkowski, M.(2002), Beck, C. T., Bernal, H. \&Froman, R. D. (2003).

Furthermore the process known as centering (Brislin, R. W. (1970), wherein the SL and the TL of a tool are bothof equal importance, must be extensively utilized. This procedure is often referred to as forwardtranslation (McDermott \&Palchanes, 1994). As Brislin (1970, 1980) suggests, a good practice for the translation is to employ at least two bilingual translators' authorities that may be familiar with the research, one to translate forward and the other to translate in the original language without having seen the original text. The differences that have occurred during the process are negotiated between the two bilingual translators (Brislin, 1970). The translation process in this study was conducted in an independent way by two forward-translators and 2 back-translators who were the counseling psychologist imminent in both English and Malay language. The forward and back-translated versions were reconciled in producing a harmonized version of MCSI-M. The meaning and content remained unchanged throughout the translation process. We used the recommended size of the sample of 10 Malaysian care providers between 21 and 60 years of age, who speak fluent Malay language for the pilot test of MCSI-M. The ease of understanding and interpretations of all the elements were checked. The face validity has been very satisfactory. The final version of the MCSI-M has been revised to ensure a satisfactory face, content, semantic and conceptual equivalence. The validity of the content was acceptable, judging from the content experts concerned by the Malaysian Institute of Translation \& books (formerly known as the National Institute of Malaysia to translation).All analyses in the study were conducted using SPSS for Windows version 22.0 (SPSS Inc., 2013).

\subsection{The study participants}

The study protocol was approved by the Research and Ethics Committee for research involving Human Subjects University Putra Malaysia (JawatankuasaEtika University PenyelidikanMelibatkanManusia JKEUPM).

The objective participants were the care providers of the dependent elderly (above 60) with Parkinson's disease in the KLANG valley, Malaysia. To access the target population, the researcher drew to the Association of Parkinson Malaysia (MPDA) and University Kebangsaan Malaysia (UKM) Medical Centre, also known as Hospital CanselorTuankuMuhriz is one of the four university hospitals in Malaysia, for care providers that usually accompany patients. The size of the eligible study sample was $\geq 50$ care providers, which has been suggested as a reasonable number of cases to ensure statistical power of correlation and the regression analysis (Green, S.B 1991). The researcher, a trained and certified psychological counselor manages the test individually to 53 participants in May 2017. Participants $(n=50)$ have given their informed consent after the nature of the study was explained to them. All subjects were literate, cooperative and able to understand the Malay language (which is the official language of Malaysia), only 3 were not eligible because they were not competent in English or the Malay language and also not keen to participating in the study. 
The inclusion criteria was as follows: 1) Malaysia citizen residing in Klang valley multiethnic informal care providers at the age of 18 years or more with different education and socio-economic background, 2) has agreed to participate in this study 3 ) identified by the dependent elderly parents or relative as primary care provider, 4) The care provider will be able to understand and speak in English or the Malay language sufficiently, and will be capable of giving their informed consent. As regards to the exclusion criteria, participants: 1) had serious chronic diseases affecting the function of cardio-pulmonary function, 2) were being treated for severe mental disorders or with uncontrolled mood disturbances, 3) had thoughts of selfharming or to commit suicide in 6 months before, 4) Those whose care recipients is dead before the commencement of the study, 5) persons who were not competent in English or the Malay language.

\subsection{The administering and interpretation of MCSI-M}

The researcher has explained in the first place to the potential care provider of the dependent elderly with Parkinson's disease about the difficulties and challenges which face both patients and care providers, before the researcher administer the index. Megan Thornton, Shirley S. Travis (2003) have also indicated that all care providers either formal or informal should understand that the caregiving strain increases the risk of become very physically and emotionally tired, potentially leading to the institutionalization of the patient.

The response to 13 items of the Malay version of Modified Caregiver Strain Index (MCSI-M), where the statements receive a numeric score of "yes", on a regular basis $=2$; while "yes" sometimes = 1; and "no" $=0$. Participants are asked to checkmark each of the statement best describes his personal situation in regards to caregiving. Match all marks in each column and multiplied by the corresponding value (2, 1 or 0 ). As a result, adds these subtotals for obtaining a total score. The score goes from 0 to 26 , where 0 indicates no caregiving strain and 26 indicating the extreme tension of caregiving strain.

\section{Results}

\subsection{Characteristics of the participants}

Table 1 demonstrates the variables of socio-demographic for informal care providers agreed to participate in the study $(n=50)$.. The age ranges from 21 to 74 years, with an average of 40.74 years. Twenty nine $(58 \%)$ of care providers in this study were women, in line with the many functions as: hands on health care provider, care manager, friend, and even companion that traditionally still generalizable to ladies. Chinese, India and others had to make a 34, 38, 26, and 2percent of all participants, respectively. About $8(16 \%)$ of care providers were educated up to the secondary level, while $40(80 \%)$ received tertiary education. Forty two (84\%) of the subjects were employed. There were about twenty eight $(56 \%)$ of those who live with the care recipient providing assistance. More than half of the subjects were children (66\%), sixteen (32\%) spouses and only one (2\%) others (friend or relative).

Table 1. Caregiver socio-demographic characteristics $(\mathbf{n}=\mathbf{5 0})$

\begin{tabular}{|l|c|c|c|}
\hline \multicolumn{2}{|c}{} & \multicolumn{2}{c|}{ Caregivers } \\
\cline { 3 - 4 } \multicolumn{2}{c|}{} & $\begin{array}{c}\text { Frequency } \\
(\mathrm{n})\end{array}$ & $\begin{array}{c}\text { Percentage } \\
(\%)\end{array}$ \\
\hline \multirow{3}{*}{ Gender } & Male & 21 & 42 \\
\cline { 2 - 4 } Ethnicity & Female & 29 & 58 \\
& Malay & 17 & 34 \\
\cline { 2 - 4 } & Chinese & 19 & 38 \\
\cline { 2 - 4 } Educational & India & 13 & 26 \\
\cline { 2 - 4 } Level & Others & 1 & 0 \\
\cline { 2 - 4 } & Nil & 0 & 4 \\
\hline Employment & Primary & 2 & 16 \\
\cline { 2 - 4 } & Secondary & 8 & 80 \\
\hline
\end{tabular}




\begin{tabular}{|l|c|c|c|}
\hline Status & No & 8 & 16 \\
\hline \multirow{3}{*}{ Staying with patient } & Yes & 28 & 56 \\
\hline \multirow{3}{*}{ Relationship with patient } & No & 22 & 44 \\
\cline { 2 - 4 } & Spouse & 16 & 32 \\
\cline { 2 - 4 } & Children & 33 & 66 \\
\cline { 2 - 4 } & Others (relative/friend) & 1 & 2 \\
\hline
\end{tabular}

\subsection{Descriptive statistics of the items}

The consistent internal reliability of the instrument was tested using a correlation matrix of 10 conceptual framework learning outcomes. We use the Alpha Cronbach criterion to produce an internal consistency reliability: Excellent $(\alpha>0.9)$, Good $(0.7<\alpha<0.9)$, Acceptable $(0.6<\alpha)<0.7)$, bad $(0.5<\alpha<0.6)$ (Kline, 2000; George \&Mallery, 2003). The frequency distribution of the single instrument elements showed that most of the response options are well utilized as shown in Table 2. Cronbach's alpha for MCSI-M-13 is 0.75 , indicating that the scale had a good Internal consistency.

\section{Discussion}

MCSIis a short, and convenient to use and is a self-administered tool. Long-term household care providers are no longer at ease with the dichotomous preference in CSI; the modified device provides the opportunity to select a media category response that is an excellent fit to some situations (Travis et al., 2003). MCSI make clear and update some of the factors of the authentic tool. According to Thornton and Travis (2003) the internal reliability coefficient is barely higher $(=90)$ than the coefficient at the start mentioned for CSI in 1983 (= 86). The three-step translation manner ensures that the translated questionnaire continues the thinking of the original Modified Caregiver Strain Index (MCSI) questionnaire. The Malaysian version of MCSI has been concluded to have a correct face and content material validity. It also has correct interior coherence reliability as proven by using the Cronbach,s Alpha 0.75. The original English version had internal consistency of 0.90 (Thornton, M., \& Travis, S.S. (2003). The internal consistency for the Turkish version was 0.77 (Ugur O, Fadiloglu C. (2010). The Caregiver Modified Caregiver Index (MCSI) for Philippine Healthcare Professionals is a questionnaire of only 11 questions addressing four major caregiver role strain areas: physical, personal, emotional and financial. Each item can be solved by a three-point Likert scale. The sum of the scores of all the elements to determine if a care provider has stress. A score of $\leq 23$ is normal, 24-28 shows the propensity to deformation and $\geq 29$ means severe deformation of the care provider (By: Bautista MT, et.al.,(2007), cited in Panganiban-Corales, A. T., \& Medina, M. F. (2011). In conclusion, a good internal consistency of reliability, MCSI-M could be better choice to assess the stress level experienced by informal care providers in the population of Malaysia.

In this study the reseacher utilized convenience sampling, which is useful for descriptive and correlational studies in relatively new research areas (Burns N, Grove S (2005). Several reasons for using this method are: it is difficult to create a list to make a random selection when the goals of the study do not need accurate results, such as in bio-psycho-social surveys; Or when the researcher is interested in a population of only a few cases they may be available for study and they should serve as a sample of the population such as the informal caregivers of dependent elderly people with Parkinson's disease.

There were several limitations in this study. Since the subjects were not randomly selected, the participants can not represent the ethnic composition of the general population of Malaysia.The Department of Information census (2015), denoted that the ethnic composition of Malay (Malay or Muslim), Chinese Malaysian, Indian Malaysia, non-Malay Bumiputera and other indigenous was 52.24, $25.52,12.12$, and 1.32, percent, respectively, in the general population of Selangor state. According to the WorldAtlas.com census (2017), the ethnic composition of Malay (Malay or Muslim), Chinese malaysian, non-Malaysian Bumiputera and other indigenous, indian, malaysian and other groups was 50.1, 22.6, 11, 8.6,7 and 8.8 percent, respectively, in the general population of Malaysia. Therefore, Malaysian ethnicity in this study was sub-represented at state and national level. By contrast, Chinese ethnicities have been 
over-represented at both levels in this study. It is recommended that to make a generalized assumption a more representative sample of Malaysian population is needed.

Table 2. Frequency of positive responses to the M-CIS-M questionnaire $(n=50)$

\begin{tabular}{|l|l|c|c|}
\hline Question number & Response \\
\cline { 2 - 3 } & $\begin{array}{l}\text { Tidursayaterganggu (sebagaicontoh: } \\
\text { individudibawahjagansayanaikdanturundarikatilataumerayau- } \\
\text { rayaupadawaktumalam) }\end{array}$ & 33 & 17 \\
\hline Q2 & $\begin{array}{l}\text { Khidmatpemjagaanadalahmenyusahkan (sebagaicontoh: bantuan yang } \\
\text { diberikanmengambilterlalubanyak masa ataupemanduan yang } \\
\text { jauhuntukmenghulurkanbantuan) }\end{array}$ & 35 & 15 \\
\hline Q3 & $\begin{array}{l}\text { Khidmatpenjagaanmerupakansuatubebanfizikal (sebagaicontoh: } \\
\text { mengangkatseseorangkekerusiataumenurunkanseseorangdaripadakerusi; } \\
\text { usahaatautumpuandiperlukan) }\end{array}$ & 33 & 16 \\
\hline Q4 & $\begin{array}{l}\text { Khidmatpenjagaanmengehadkankebebasandiri(sebagaicontoh: bantuan } \\
\text { yang diberikanmengehadkan masa lapangatausayatidakbolehmenziarahisesiapa) }\end{array}$ & 36 & 13 \\
\hline Q5 & $\begin{array}{l}\text { Terdapatpenyesuaiankeluarga (sebagaicontoh: bantuan yang } \\
\text { diberikantelahmengganggurutinsaya; tiadaprivasi) }\end{array}$ & 39 & 11 \\
\hline Q6 & $\begin{array}{l}\text { Terdapatperubahandalamperancanganperibadi (sebagicontoh: } \\
\text { sayaterpaksamenolaksuatupekerjaan; sayatidakdapatpergibercuti) }\end{array}$ & 41 & 9 \\
\hline Q7 & $\begin{array}{l}\text { Terdapatkeperluan lain untuk masa saya(sebagaicontoh: ahlikeluarga yang } \\
\text { lain memrlukansaya) }\end{array}$ & 41 & 9 \\
\hline Q8 & $\begin{array}{l}\text { Terdapatpenyesuaianemosi (sebagaicontoh: } \\
\text { pertengkaranteruktentangkhidmatpengajaan) }\end{array}$ & 37 \\
\hline Q9 & $\begin{array}{l}\text { Sesetengahtingkahlakumembimbangkan (sebagaicontoh: inkontinens; } \\
\text { individu di bawahjagaansayamempunyaimasalahmengingatibenda; atauindividu } \\
\text { di bawahjagaansayamenuduh orang lain mengambilbarang) }\end{array}$ & 37 & 13 \\
\hline Q10 & $\begin{array}{l}\text { Sesuatu yang menyedihkanapabilamengetahuiindividu di } \\
\text { bawahjagaansayatelahbanyakberubahberbandingdirinyadahulu } \\
\text { (sebagicontoh: beliauberbezadaripadadirinyasebelumini) }\end{array}$ & $\begin{array}{l}\text { Terdapatpenyesuaiankerja (sebagaicontoh: } \\
\text { sayaperlumengambilcutiuntukmemberikankhidmatpenjagaan) }\end{array}$ \\
\hline Q13 & $\begin{array}{l}\text { Khidmatpengajaanmerupakansuatubebankewangan } \\
\text { Saya rasa benar-benarterbeban (sebagaicontoh: sayabimbangtentangindividu } \\
\text { di bawahjagaansaya; sayakhuatirtentangcarauntuksayamenanganinya) }\end{array}$ & 36 \\
\hline
\end{tabular}

\section{Conclusion}

It is well-studied that caregiving can have unfavorable and hazardous effects on the care-recipient's care and the care provider themselves. The prevalence of stress amongst casual care provider may additionally extend the chance of caregiving burnout and this can trigger the family members' selection to institutionalize the established elderly. When given normally (perhaps annually), the MCSI-M index can be used to help reveal the persevering with consequences of caregiving on family individuals as properly as any casual care companies of Malay language orientation. As Parkinson ailment irritate over time, fitness care authorities be asking care vendors to entire the questionnaire at least as soon as a year, so that they can work with them to identify approaches to alleviate their strain. The Modified Malay Caregiver Strain Index (MCSI-M) has a precise face and content material and interior consistency (Cronbach's Alpha 0.75). MCSI-M is a reliable device for assessing the care provider's experience, will be needed properly into the foreseeable future in Malaysia 


\section{References}

Bautista MT, Yu-Maglonzo EI (2007). Modified Caregiver Strain Index. The Filipino Family Physician, 45(1):1-7.

Beck, C. T., Bernal, H. \& Froman, R. D. (2003) Methods to document semantic equivalence of a translated scale. Research in Nursing and Health, 26 (1), 64-73.

Bonnie Teschendorf, Carolyn Schwartz, Carol Estwing Ferrans , Ann O'Mara, Paul Novotny , Jeff Sloan (2007). Caregiver Role Stress: When Families Become Providers. Cancer Control 14 (2), 183-189.

Brislin, R. W. (1970). Back-translation for cross-culture research. Journal of Cross-Cultural Psychology, $1,185-216$.

Brislin, R. W. (1980). Translation and content analysis of oral and written materials. In H. C. Triandis \& J. W. Berry (Eds.), Handbook of cross-cultural psychology: Methodology. (pp. 89-102). Boston: Allyn and Bacon.

Burns N, Grove S (2005). The Practice of Nursing Research: Conduct, Critique, and Utilization. Elsevier and Saunders.

Chen ML, Hu LC. (2002).The generalizability of Caregiver Strain Index in family caregivers of cancer patients. International Journal of Nursing Studies; 39: 823-829.

Deeken JF, Taylor KL, Mangan P, Yabroff R, Ingham JM (2003). Care for the caregivers: A review of self-report instruments developed to measure the burden, needs, and quality of life of informal caregivers. Journal of Pain and Symptom Management; 26: 922-953.

Department of Information, Ministry of Communications and Multimedia, Malaysia. 2015. Archived from the original on 12 February 2016. Retrieved June 2017.

Department of Statistics, Malaysia (2016). Retrieved: 16 May 2017. https://www.dosm.gov.my

Department of Statistics Malaysia. (2014) Statistical Releases, [Online], Available: http://www.statistics.gov.my/portal/index.php?option. [accessed 01Jun 2017].

Deva, P. M. (2004). Malaysia mental health country profile. International Review of Psychiatry, 16, 167176. http://dx.doi.org/10.1080/09540260310001635203

Freedman, V.A., L.G. Martin, and R.F. Schoeni, (2002). Recent trends in disability and functioning among older adults in the United States: a systematic review. JAMA, 288(24): p. 3137-46.

Green, S.B. (1991) How Many Subjects Does It Take to Do a Regression Analysis. Multivariate Behavioral Research, 26, 499-510. http://dx.doi.org/10.1207/s15327906mbr2603_7

George, D., \& Mallery, P. (2003). SPSS for Windows step by step: A simple guide and reference 11.0 update (4th ed.). Boston: Allyn \& Bacon.

Hansen.L, Archbold P.G., \& Stewart B.J, (2004). Role strain and case in decision-making to withdraw oe withhold life support for elderly relatives. Journal of Nursing Scholarship. 36, 233-238.

Hilton, A. \& Skrutkowski, M. (2002) Translating instruments into other languages: development and testing processes. Cancer Nursing, 25 (1), 1-7.

IBM Corp. Released 2013. IBM SPSS Statistics for Windows, Version 22.0. Armonk, New York: IBM Corp.

Jones, E. G. \& Kay, M. (1992) Instrumentation in cross-cultural research. Nursing Research, 41 (3), 186188.

Jones, P. S., Lee, J. W., Phillips, L. R., Zhang, X. E. \& Jaceldo, K. B. (2001) An adaptation of Brislin's translation model for cross-cultural research. Nursing Research, 50 (5), 300-304.

Kline, p. (2000). The handbook of psychological testing (2nd.ed.) pp.13. London:Routledge.

McDermott, M. A., \& Palchanes, K. (1994). A literature review of critical elements in translation theory. Journal of Nursing Scholarship, 26(2), 113-117.

Megan Thornton, Shirley S. Travis (2003). Analysis of the Reliability of the Modified Caregiver Strain Index. J Gerontol B Psychol Sci Soc Sci; 58 (2): S127-S132. doi: 10.1093/geronb/58.2.S127. Cited from Oxford University Press (2017).

Othman Z, Wong ST. (2014). Validation of Malay Caregiver Strain Index. Eastern Journal of Medicine, 19: 102-104. Retrieved from: https://www.journalagent.com/ejm/pdfs/EJM_19_2_102_104.pdf 
Panganiban-Corales, A. T., \& Medina, M. F. (2011). Family resources study: part 1: family resources, family function and caregiver strain in childhood cancer. Asia Pacific Family Medicine, 10(1), 14. http://doi.org/10.1186/1447-056X-10-14

Post M, Festen H, van de Port I, Visser-Meily A (2007). Reproducibility of the Caregiver Strain Index and Caregiver Reaction Assessment in partners of stroke patients living in the Dutch community. Clinical Rehabilitation; 21:1050-1055.

Robinson, B.C. (1983). Validation of a Caregiver Strain Index. Journal of Gerontology, 38(3), 344-348. (Betsy C. Robinson)

Shanti R Rao and Potluri M Rao, Raosoft Inc., (2009). http://www.raosoft.com/samplesize.html

Sherwood, P. R., Given, B. A., Doorenbos, A. Z., \& Given, C. W. (2004). Forgotten voices: Lessons learned from bereaved caregivers of persons with a brain tumour. International Journal of Palliative Nursing, 10, 67-75. Retrieved from www.internurse.com

Sperber, A. D. (2004) Translation and validation of study instruments for cross-cultural research. Gastroenterology, 126 (1), S124-S128.

Sousa, V. D. and Rojjanasrirat, W. (2011), Translation, adaptation and validation of instruments or scales for use in cross-cultural health care research: a clear and user-friendly guideline. Journal of Evaluation in Clinical Practice, 17: 268-274. doi: 10.1111/j.1365-2753.2010.01434.x

Sousa, V. D., Zauszniewski, J. A., Mendes, I. A. C. \& Zanetti, M. L. Jones (2005) Cross-cultural equivalence and psychometric properties of the Portuguese version of the depressive cognition scale. Journal of Nursing Measurement, 13 (2), 87-99.

Thornton, M., \& Travis, S.S. (2003). Analysis of the reliability of the Modified Caregiver Strain Index. The Journal of Gerontology, Series B, Psychological Sciences and Social Sciences, 58(2), p. S127-S132.

Travis, S.S., Bernard, M.A., McAuley, W.J., Thornton, M., \& Kole, T. (2003). Development of the Family Caregiver Medication Administration Hassles Scale. The Gerontologist, 43(3), 360-368.

Ugur O, Fadiloglu C. (2010). Caregiver Strain Index validity and reliability in Turkish society. Asian Pacific J Cancer Prev; 11: 1669-1675.Retrived from: apocpcontrol.com/paper_file/issue_abs/Volume11_No6/c\%20166975\%2011.04\%20Ozlem\%20Ugur.pdf

Van Exel J, Scholte op Reimer W, Brouwer W, et al. (2004).Instruments for assessing the burden of informal caregiving for stroke patients in clinical practice: a comparison of CSI, CRA, SCQ and self-rated burden. Clinical Rehabilitation. 18: 203-214.

Wan He, et al., (2005). 65+ in the United States: 2005, in Current Population Reports, P23-209. 2005, US Census Bureau: Washington, D.C.

WorldAtlas.com (2017). Ethnic Groups Of Malaysia. http://www.worldatlas.com/articles/ethnic-groups-ofmalaysia.html Retrieved June, 2017.

Zarit S.H., Reever K.E., Bach-Peterson J. (1980). Relatives of the impaired elderly: correlated of feelings of burden. Gerontologist, 20, 649-655.

Bibliography

Kelly, D.H., McGinley, J.L., Huxham, F.E., et al. (2012) Health-Related Quality of Life and Strain in Caregivers of Australians with Parkinson's Disease: An Observational Study. BMC Neurology, $12,57$. http://dx.doi.org/10.1186/1471-2377-12-57

Zavala Rojas, D. \& Dorer, B. (2013) “A Mixed Method Approach to Link Translation Deviations and Measurement Quality” Mimeo.

Crystal (1991) defined translation as a process where "the meaning and expression in one language (source) is tuned with the meaning of another (target) whether the

Crystal, D. (1991). The Cambridge encyclopedia of language. Cambridge, UK: Cambridge University Press. 
